\title{
Essay
}

\section{National Loyalty, Communalism, and the Professional Identity of Lawyers}

\author{
Sanford Levinson*
}

\section{AN ENCOUNTER IN HUNGARY}

I begin with the story of an encounter in Hungary that occurred in the summer of 1992, when I was participating in a seminar for Eastern European lawyers by teaching a sequence of classes on the American view of the legal profession. The idea was that Eastern European lawyers, who were themselves participating in the design of institutional structures-including an organized bar-appropriate to the new political orders emerging in those countries, might learn something from the American experience. As we all know, however,

* I am grateful to Jack M. Balkin, Philip Bobbitt, Cynthia Y. Levinson, and Martha Minow for their responses to earlier versions of this essay, as well as to the faculty colloquium at Vanderbilt University School of Law. As a reader for this journal, Robert W. Gordon made unusually helpful comments on the draft that I submitted to it. I am particularly grateful to Williams College, and to Gary Jacobsohn especially, for inviting me to participate in a lecture series on the meaning of citizenship, thus providing me with the occasion to begin thinking through some of the difficult problems raised by the issue of citizenship in the contemporary world. 
the learning process can work two ways, and it is not always so easy to distinguish the teachers from the taught.

A central question that I wanted to explore with these lawyers concerned the conditions that could legitimately be placed by the state on entry to the practice of law. Thus I presented several cases of the United States Supreme Court dealing with constitutional limitations on state regulation of the bar. For example, could a state limit membership in the bar to "loyal Americans," defined as those untainted by contact with "subversive" ideas or by membership in organizations like the Communist Party? Several states had attempted just such limitations, which drew mixed responses from the Supreme Court. The final outcome of these cases, though, was the unconstitutionality of a state's using membership in the Communist Party per se to prevent individuals from becoming lawyers. ${ }^{1}$ The state was entitled to ask applicants about membership, and to use their answers as the basis for further conversation about their commitment to illegal goals of the Party. However, simple Party membership-and even support of the desirability of radical transformation of the polity into a "proletarian dictatorship"-could not be disqualifying.

As one might imagine, these cases generated spirited discussion among the Hungarian, Ukranian, Georgian, Bulgarian, and other Eastern European lawyers gathered together in Rackeve, a small town outside of Budapest. Most of them espoused views far less tolerant than current American constitutional doctrine in regard to the rights of Communist lawyers. They tended to view American liberals like myself as almost laughably (or tragically) naive in our formal indifference to the political beliefs, including hostility to some basic norms of liberal democracy, of those who would enter the legal profession. They would scarcely entrust the bar to those whose ideological loyalties were suspect.

Overtly ideological restrictions on entry to the bar are, of course, only one example of state regulation. Another concerns one's formal status as a member of the state, a topic that also provoked considerable discussion. The most vigorous discussant in regard to this issue was a Latvian, Imma Jansone, who was employed by the Latvian equivalent of the state bar association. Although she had expressed her share of skepticism about welcoming Communists into the bar, the principal conflict between us took place over a quite different case, In re Griffiths, ${ }^{2}$ a 1973 Supreme Court decision striking down

1. Baird v. State Bar, 401 U.S. 1 (1971).

2. 413 U.S. 717 (1973). 
a Connecticut law limiting membership in the state bar to citizens of the United States.

Ms. Jansone vigorously disagreed with my endorsement of the Court's decision, at least insofar as I used it to suggest that the Latvian and other Eastern European bars should not restrict membership to nationals of their respective countries. She defended the desire of the local bar to restrict legal practice in Latvia not only, and reasonably, to those who could pass an examination demonstrating sufficient knowledge of Latvian law, but also-more debatably-to citizens of the newly revived country and speakers of its language. As we began our discussion, I assumed that we simply represented the conflict between my own (highly desirable) liberal universalism and her (quite dubious) tribal parochialism, especially in light of the fact that emphasis on Latvian citizenship and linguistic abilities is often a coded way of denying full rights to longtime (and, in many cases, lifetime) Russian residents of Latvia who would be denied such citizenship. ${ }^{3}$ As the discussion progressed, though, I realized that the situation may be more complex than I had first thought, that there may in fact be a defensible rationale for at least some of the limitations on admission to the bar that Ms. Jansone was proposing. My thoughts then turned to whether the rationale for her position was substantially dependent on the specific circumstances of Latvia or, indeed, if it might have implications even for our own very different political and cultural situation here in the United States. What follows is an attempt to address these questions, an exploration that involves nothing less than reflecting on the intersections, if any, of the duties of citizenship and the roles of modern lawyers.

3. See, e.g., Michael IgNatiefF, Blood and BelongING: JoURNeys INTO THE NEW NATIONALISM 168 (1994), where he notes that the attempt by Latvia to restrict citizenship to Latvian-speakers is quite likely an attempt to disenfranchise those "ethnic Russians [who] are in a majority in Riga, the capital. . . . Ethnic Russians born and brought up in Latvia lose their citizenship in the new republic unless they learn the rudiments of Latvian." It is clearly possible to have a multilingual society where some citizens speak only one of the languages, as in Switzerland, Belgium, or Canada. Perhaps the United States should be added to this list, even though it obviously has no "official" alternatives to its principal language, unlike the three countries mentioned above, which are "officially" bilingual or multilingual. In any event, would it be illegitimate for a state within the United States to restrict entrance to the bar to those who can speak (at least) English? Only if one confidently answers this question in the affirmative can one simply dismiss the Latvian language restriction, which may be not only anti-Russian (which it most certainly is), but also an attempt to assure the maintenance of Latvian as a living language in a world where its speakers are surrounded (and potentially swamped) by those proficient in other languages with no desire to learn Latvian. Ignatieff has an excellent discussion of the language issue in his analysis of Quebec. Id. at 143-77. 


\section{THE LAWYER AS CITIZEN AND AS FRIEND}

I want to adapt a question- "Can a good lawyer be a good person?"-that begins a famous article by Charles Fried on "the moral foundations of the lawyer-client relationship." "What if, for example, a lawyer worked to vindicate the legal rights of a pornographer, or of a landlord seeking eviction of a poor family for failure to pay the rent, or, as I have done, of the Ku Klux Klan to march down the main street of the capital of Texas? Fried answered his question (and countered any such examples) with a resounding affirmation of the lawyer's role. In a reasonably just society, he argued, it is always morally admirable to help persons achieve whatever the law entitles them to do, even if the lawyers in question would choose to lead their own lives in considerably different ways from those of their clients.

As has been pointed out by his many critics, ${ }^{5}$ Fried's question is surely too broad, for only the most rabid antilawyers have argued that the lawyer cannot be a good person, that it would be enough to know that persons are lawyers in order to identify them as bad. ${ }^{6}$ The more sensible question is surely something like, "To what extent, and under what circumstances, might the attributes of a good lawyer conflict with those of a good person?"

My adaptation of Fried's question is as follows: Will a good lawyer, as defined by fidelity to the norms of professional conduct, necessarily be a good citizen? If the answer is no, then one must assert potential distinctions between the attributes of good (i.e., professionally honorable) lawyering and of good citizenship. Someone identified by standard American professional norms as a first-rate lawyer would at the same time be potentially describable as a questionable, even "bad," citizen. A full exploration of this question would require nothing less than elaboration of the notions of both "good lawyering" and "good citizenship." The latter, in particular, would have to be distinguished from what might be termed "mere" citizenship, the possession of an "external" legal status as a citizen of a given polity that is not significantly intertwined with an "internal," phenomenological sense of strong political identity and commitment to shared political purposes. "Mere citizens" may be similar to what

4. Charles Fried, The Lawyer as Friend: The Moral Foundations of the Lawyer-Client Relation, 85 YALE L.J. 1060 (1976).

5. The classic critique is Edward A. Dauer \& Arthur Allen Leff, Correspondence, The Lawyer's Friend, 86 YALE L.J. 573 (1977).

6. To accept any such argument would, among other things, be especially difficult for those of us who actually teach in law schools; for then we would presumably have to recognize ourselves as inevitable collaborators with evil. 
Michael Walzer once described as "alienated residents," individuals who may live within a formal political space but for whom that status has almost no affective meaning.?

I turn once more to Fried's article, in which he presented a model of the lawyer as the client's "friend." According to Fried, "like a friend [your lawyer] acts in your interests, not his own; or rather he adopts your interests as his own. I would call that the classic definition of friendship." 8 Whatever the problems with Fried's metaphor of the lawyer as the client's "friend"-one does not, for example, often hire one's friends-they do not preclude us from adapting it to the role of the citizen, where it may prove considerably more illuminating.

When we describe someone as a "good citizen," rather than a "mere citizen," do we not refer in some sense to a genuine friend of the polity, someone devoted to its interests and willing, if necessary, to subordinate more selfish interests to those of the polity? One name for this kind of citizenship, of course, is patriotism. As Francis Lieber wrote in the middle of the nineteenth century, "Without patriotism ... all must dissolve into dreary, heartless egoism. But even to regret such an occurrence and strive to prevent it requires patriotism." Some versions of such civil friendship are almost frightening in their monomania. I think, for example, of Rousseau's stunning invocation in Emile of the Spartan mother who, upon being told by a messenger that her five sons had just died in a battle, responded, "You fool. Did we win the battle or not?"10 I presume that most of us find this exemplary not of friendship but of totalitarianism, for it seems to extinguish any noncivic loyalties and attachments. I think it too pessimistic, though, to suggest that we are forced to choose either Spartan totalitarianism or celebration of a desiccated notion of citizenship whose sole meaning becomes, in effect, the possession of rights against the state without any concern for duties owed it. Indeed, criticisms of rights-centeredness and emphasis on claims of the community are pervasive themes in both

7. See Michael Walzer, Obligations: Essays on Disobedience, War, and CITIZENSHIP 113-14 (1970). "[T] he alienated residents of the modern state . . . are probably far more numerous than are the resident aliens," says Walzer, who goes on to say that whatever obligations are felt by the politically alienated, "these obligations do not involve what the ancients called political 'friendship' and do not bind [them] to share the political purposes or the political destiny of [their] fellow residents ...." Id. at 114 .

8. Fried, supra note 4, at 1071 .

9. 1 FRANCIS LiEber, MANUAL of POLITICAL ETHICS 89 (1881 ed.) (1855), quoted in Paul Carrington, The Theme of Early American Law Teaching: The Political Ethics of Francis Lieber, 42 J. LEGAL EDUC. 339, 369 (1992).

10. Jean-Jacques Rousseau, Emile, or ON Education 40 (Allan Bloom trans.. 1979). 
academic political theory and books written for more general audiences. $^{11}$

In this context I am reminded of the 350-year-old oath taken by new voters in Connecticut. They must "solemnly swear" to "be true and faithful to the state of Connecticut, and to the constitution and the government, thereof ... and to the constitution of the United States." 12 More to the point, the oath states that "whenever you are called upon to give your vote or choice touching any matter which concerns this state or the United States, you will do this in a manner which you shall judge contributes to the best interests of Connecticut and the nation, without respect or favor of any person," including the person of oneself. ${ }^{13}$ We might also remember President Kennedy's famous plea in his inaugural address to the citizenry to "ask not what your country can do for you; ask what you can do for your country." 14

"Good citizenship" is therefore far more than merely obeying the laws, just as being a good parent is, presumably, far more than simply refraining from child abuse. To earn commendation in either role requires a disposition of concern and care for others, including a willingness, when necessary, to subordinate one's own desires or interests to those of others (even as children must learn that parents have their own legitimate desires and interests which must be recognized). Of course, the purpose is to create a community, whether we call it the polity or the family, that enjoys a status quite different from a simple collection of the discrete, separated individuals counted as its members. One of the characteristics of such communities, presumably, is what Dean Anthony Kronman calls "political fraternity" - bonds of sympathy among its members "despite the differences of opinion that set them apart on questions concerning the ends, and hence the identity, of their community." 15

I come, then, to the title of this essay, National Loyalty, Communalism, and the Professional Identity of Lawyers. I am interested in the extent to which, in the words of the sociologist Steven Cohen,

11. For high political theory, see, e.g., MICHAEL SANDEL, JUSTICE AND THE LIMITS OF LIBERALISM (1982). For more popular books written by academics, see ROBERT BELLAH ET al., Habits of THE Hearr (1985); MARY ANN Glendon, Rights TalK: The IMPOVERISHMENT OF POLITICAL DISCOURSE (1991). Even some liberal critics of the new communitarianism nonetheless recognize the need for individuals to have social commitments. See, e.g., NANCY ROSENBLUM, ANOTHER LIBERALISM: ROMANTICISM AND RECONSTRUCTION OF LIBERAL THOUGHT (1987).

12. See Conn. Gen. STAT. § 1-25 (1987).

13. See id. I discuss the oath in Suffrage and Community: Who Should Vote?, 41 FLA. L. REV. 545, 560-61 (1989).

14. BARTLETT'S QuOTATIONS 74 (Justin Kaplan ed., 16th ed. 1992).

15. ANTHONY T. KRONMAN, The LOST LAWYER: FaIling IDEALS of the Legal PROFESSION 93 (1993). 
"professions are potential communities; and, as such, they might serve as surrogates and replacements" for more typical kinds of communities. Cohen even suggests that "some professions could conceivably rival ethnic and religious communities in many ways." 16 Interestingly enough, Cohen does not list political communities among the potential competitors for feelings of loyalty and commitment. Is it possible, however, that the professional community could even become a rival, in some significant sense, to the polity? If that should be the case, is it a cause for worry, or might we view such professional communities as just one more tile of a mosaic that celebrates cultural pluralism and the presence of mediating institutions that can resist the imperial claims of the state?

No one familiar with contemporary American culture can avoid the issue of multiculturalism and the ostensible challenges posed by cultural fragmentation to standard notions of social and political unity. Multiculturalism comes in many different disguises, though. We should be as aware of the potential conflicts generated by cultures of professionalism as we are of those caused by racial, ethnic, or religious affiliations, even if, to be sure, these latter problems are more likely to eventuate in bloodshed. Moreover, to focus on "fragmentation" may be misleading if it suggests that the only threat to national unity comes from subcommunities within the territorial polity. One might also note the possibility of transnational loyalties that go beyond the nation-state. The most obvious example is the Roman Catholic Church. For our purposes, one might ask if the internationalization of the legal profession will also lead to a crossnational professional identity significantly independent of the national identity provided by the passport carried by a particular lawyer.

\section{What Do LAWYERS DO?}

Before one can cogently discuss the state regulation of lawyers, including limiting membership in the profession to citizens, one obviously must have an image of what it is that lawyers do (as well as what it is that citizens do). One of the central tasks I set for myself during my sojourn in Hungary, therefore. was elaborating to the Eastern Europeans a description of how American lawyers conceptualized their own role. What, precisely, do American lawyers view themselves as doing? To begin answering this question I assigned to my students the seminal 1897 speech by Oliver Wendell Holmes, "The

16. Steven M. Cohen, American Modernity AND Jewish Identity 84 (1983). I explore some of these themes in Identifying the Jewish Lawyer: Reflections on the Construction of Professional Identity, 14 CARDOzo L. REV. 1577 (1993). 
Path of the Law."17 Delivered to law students at Boston University as a way of explaining to them the nature of the vocation they had chosen, Holmes's speech is, I believe, the most important explanation of the legal profession ever penned by an American-not least because of its decidedly unsentimental view of the lawyer's role.

What for Holmes is the task of the ordinary lawyer? Is it, for example, the careful study of the social good, or of norms of justice, and the conveying to clients the results of such study? Not especially: Holmes sweeps aside the traditional notion of the lawyer as a civicrepublican patriot and replaces it with the image of a businessman selling a commodity, which is knowledge about the actual behavior of public officials who possess the capacity to bring public force to bear on the lawyer's clients. The "business" of the lawyer is simply the prediction of the likely behavior of public officials, particularly judges, in response to the acts of citizens. Law is ascertained through acute observation of political behavior-"experience"-rather than through dazzling "logical" analysis that might be altogether irrelevant to the actual behavior found within a particular society. Holmes's method entails a strict analytical separation between description and assessment-that is, between law and morality. He leaves no doubt that the role of the lawyer is simply to present accurate descriptive accounts to clients who will then base their behavior on a desire to avoid unfortunate encounters with, and the costs imposed by, public authority.

Holmes's positivism thus contains a decidedly skeptical view about the moral status of public authority. Although Holmes had been wounded three times during the great struggle of 1861-65 (itself the most profound clash about the meaning of American citizenship in our own history), he generally viewed life as a relentless struggle among brutally contending competitors, in which survival was its own justification. "Law" itself was simply an assertion of power, and the lawyer's role was merely the detached purveying of a certain kind of information about the likely use of public force.

What the skilled lawyer knows is the "law in action" rather than what Roscoe Pound, a contemporary of Holmes, disdainfully dismissed as the "law on the books," which was often utterly ignored even by public officials. Holmes described, and some would even say helped to create, a client who simply wishes to know, concretely, what is likely to happen upon a certain course of conduct. An important analytical construct developed by Holmes is that of the "bad man," motivated only to avoid unpleasant consequences but not concerned,

17. Oliver Wendell Holmes, The Path of the Law, 10 HARV. L. REV. 457 (1897). 
for example, with doing good, however defined, for its own sake. Holmes by no means suggested that one should avoid representing such "bad men." Indeed, "bad men" comprised much of the market for the services that Holmesian lawyers sold, since their own behavior was the product not of an internal moral compass but, rather, of the simple desire to avoid actions whose costs outweighed their benefits. And the lawyer hired by such a client is basically indifferent to the use that will be made of the information by the client.

Dean Kronman has recently offered an important analysis-part jeremiad, part call to action-of the legal profession that is strikingly anti-Holmesian in its thrust. Far from the lawyer as detached predictor, Kronman's lawyer is an embedded member of a particular political community, sharing this identity with his or her clients and with the judges who will decide their cases. ${ }^{18}$ It is this embeddedness that, among other things, generates the attribute of "statesmanship" that for Kronman defines legal practice at its best. For Kronman, "[t]he good lawyer does care about the soundness of the legal order. ... [H] e shares the judge's public-spirited devotion to it." similar argument can be found in Robert Gordon's classic "neorepublican" essay "The Independence of Lawyers."20

As Kronman himself admits (and bewails), the "lawyer as statesman" is perhaps under fatal assault for reasons ranging from internal developments within American legal education to the modern culture of the large law firm. Still, there may be at least some citizen-lawyers who practice in the United States and feel some identification with the polity and its interests. Consider, though, what might be termed "multinational" lawyers who practice law outside their polities. What precisely would it mean for them to be "statesmen" or "republicans," neo- or otherwise? After all, what polity or social order would they identify with? One notes Secretary of Labor Robert Reich's emphasis on the relationship between national attachments and the inculcation of a necessary spirit of self-sacrifice. According to Reich, "we learn to feel responsible for others because we share with them a common history ... a common culture ... a common fate." He is therefore at least somewhat wary of the "darker side of [the] cosmopolitanization" represented by multinational enterprise insofar as it generates persons who identify themselves as "world citizens, but

18. See, e.g., KRONMAN, supra note 15, at 134 ("When a lawyer gives advice to a client based upon his prediction of the future course of judicial behavior, he is engaged in an enterprise that, broadly speaking, includes the work of judges too, namely the maintenance of the rule of law in the political society to which lawyer, judge, and client all belong.") (emphasis added).

19. Id. at 145.

20. Robert W. Gordon, The Independence of Lawyers, 68 B.U. L. REV. 1 (1988); see also Robert W. Gordon, Corporate Law Practice as a Public Calling, 49 MD. L. REV. 255 (1990). 
without accepting ... any of the obligations that citizenship in a [particular] polity normally implies."21

How might this tension between the Holmesian and Kronmanian visions of legal practice be relevant to Eastern Europeans concerned with constructing radically new political orders? And how might it be relevant to us, who as Americans are the sons and daughters of Holmes but are, like Kronman (and many others), fearful of many of the features we see when observing our contemporary society? One answer is as follows: To the extent that members of the general society, including lawyers, restrict their operative definition of law to the actual enforcing behavior of public officials, then a state concerned to work its will must invest far more resources in enforcement procedures than might otherwise be the case.

The state cannot simply rely on its Holmesian members to exhibit, as a result of moral obligation, sufficient levels of compliance with the abstract commands of the state. Some citizens, as was presumably the case in pre-1989 Eastern Europe, might be tempted to reject the commands of the state because of a belief that the state was significantly-and illegitimately-detached from the underlying community. Others, more atomistic, might be equally disdainful of "community" and "state," viewing both as abstract reifications threatening the unrestrained realization of individual desires.

Public officials looking at the members of a Holmesian society, including presumably its lawyers, will see not "citizens" asking questions about public interest (and obligations) so much as egoists trying simply to maximize their self-interest. The commands of the state are viewed merely as expressions of desired conduct, but they are otherwise without any genuine obligatory force. Legal "duties" are transformed into simple "prices" extracted for the conduct in question. There is a striking similarity between Holmes's view and that of Georg Lukács, a Hungarian who was one of the leading Communist social theorists of this century. In describing a "total, communist fearlessness with regard to the state and the law," Lukács asserted that "the law and its calculable consequences are of no greater (if also of no smaller) importance than any other external fact of life with which it is necessary to reckon when deciding upon any

21. Reich's comments are quoted in Christopher Lasch, The Revolt of the Elites: Have They Canceled Their Allegiance to America?, HARPER'S, Nov. 1994, at 49. Reich is also cited for his fear about the "secession of the symbolic analysts" from membership in the ordinary polity. Id. As one can readily gather from the subtitle of his essay, Lasch, who died in 1994, was extremely fearful of the consequences of any such secession. One assumes that he would have been sympathetic to Dean Kronman's attempt to revive a more citizenship-oriented conception of lawyering. 
definite course of action."22 He compares the legal commands of the state with a train schedule: "The risk of breaking the law should not be regarded any differently than the risk of missing a train connection when on an important journey."23 Thus, a lawyer's role is apparently like that of a travel agent, though instead of train schedules she offers the client accurate information concerning the actual and predicted odds of various official responses to the client's activity. The client is no more interested in the lawyer's view regarding the "best" interpretation of the law, independent of the likelihood of that view actually being enforced by officials with power, than are most customers interested in having the travel agent insist that they really ought to travel to some place different from the destination they originally chose.

I don't want to sound overly censorious of the Holmesian (or Lukácsian) attitude, for it describes the way most of us live our lives on many occasions. The easiest way of making this point is by reference to posted speed limits. I know almost no one who believes that " 55 means 55" (and that disbelief is not merely the result of adherence to some fancy theory of linguistic indeterminacy). For most of us, " 55 " means something like " 63 ," and I suspect it would mean " 75 to 80 " if we were confident that the state police would not stop anyone traveling at such speeds. And, presumably, what would lead many of us to stop increasing our speed at $80 \mathrm{~m}$.p.h. would be as much a calculation about the risks of accident and injury to ourselves as a focus on the increased risks borne by those sharing the highways with us.

Many of us have engaged in similar predictive analyses of the law in regard to such subjects as sex, alcohol, and drugs. A Holmesian analysis also explains why most "good Americans" feel no compunctions about participating in various World Series, Super Bowl, or Final Four office pools even though they almost certainly violate the "letter" of many states' laws prohibiting public gambling. ${ }^{24}$ (And phone calls to out-of-state friends to make friendly bets bring one into violation of federal criminal law.) The tension between "law on the books" and "law in action" was, I think, at the heart of the controversy generated by President Clinton's initial nomination of Zoë Baird to be Attorney General. Many of her defenders plausibly viewed the laws on the books about private individuals hiring undocumented

22. GeORg LuKÁCS, History and Class ConsCiousness 263 (1971).

23. Id.

24. See, e.g., Kimberly Garcia, Office Wagering Not Quite So Risky, AUSTIN AM.STATESMAN, Jan. 23, 1993, at B1 (discussing office Super Bowl pools and unlikelihood of enforcement of law prohibiting them). 
aliens as honored more in the breach than in the observance; why should even a prospective attorney general be without blemish in regard to fidelity to legal formalities? ${ }^{25}$ Some of the same tensions may even be present in regard to the actual behavior we expect from those who administer toxic dumps or run savings and loan associations; at this point, of course, we may start worrying and begin asking about the possibility of encouraging a sense of genuinely shared destiny and membership in a social order as a way of taming more egoistic, asocial impulses.

Let us now return, at least figuratively, to Latvia. ${ }^{26}$ In particular, I ask you to imagine a foreign investor in Latvia motivated simply by a desire to maximize profits. That is, the investor has no particular commitment to the welfare of Latvia; any contribution to general Latvian welfare will, as suggested by classical economics, be but a happy by-product of the quest for private gains. So long as these gains are sufficient, the investor is as happy to realize them in Latvia as, say, in Thailand, or even western Massachusetts or Connecticut. But the investor will not make sacrifices merely to improve the general welfare of these societies. After all, in the contemporary world, one rarely finds large business corporations devoted to the welfare of the particular communities within which they currently operate (and from which they will often relocate once better offers come along from elsewhere). Their loyalties, if any, tend to run far more to their shareholders, who are increasingly drawn from around the world.

25. See, e.g., Stuart Taylor, Jr., Inside the Whirlwind: How Zoë Baird Was Monstrously Caricatured for the Smallest of Sins, Pounded by Press and Popular Righteousness, and Crucified by Prejudice and Hypocrisy, AM. LAWYER, Mar. 1993, at 64, 64-69. The matter of Social Security taxes is more complex, though there seems to be good evidence that Ms. Baird and her husband were in fact victims of bad legal advice rather than conscious evaders of their legal duties. In any event, even after the widespread publicity about Ms. Baird, it is unlikely that most Americans are now paying Social Security taxes for every teenager who has been paid more than $\$ 50$ in a calendar quarter to baby-sit or mow the lawn, though it is probably true that many of those who contemplate future public office are changing their behavior on this matter.

Spurred by the Baird and other "Nannygate" scandals, the 103d Congress and President Clinton recently enacted the Social Security Domestic Employment Reform Act of 1994. This law requires payment of the so-called "nanny taxes" only after an employer has paid someone $\$ 1,000$ or more in a calendar year. See, e.g. Kathy M. Kristof, New "Nanny Tax" Rules Remove Daunting Hurdles; Law "Decriminalizes" Baby-Sitters, Raises Filing Threshold and Reduces Paperwork, CHI. TRIB., Nov. 30, 1994, at C3.

26. Perhaps I should note at this point that I know almost nothing about the Latvian legal system. I assume that, like all Continental legal systems, it is code oriented rather than common law based. It may also be the case that fifty years of Soviet hegemony within Latvia has left lawyers within that country with significantly different conceptions of their role than would have been the case had the Nazi-Soviet Pact of 1939-which allowed the Soviet Union its unchallenged takeover of the Baltic states-not occurred. The discussion in the text concerns the general theoretical problem of the right of a state to attempt to control the ideological structure of the legal profession. To the extent that specific facts matter, I exercise the prerogative of law professors to stipulate them when convenient for my argument. 
Indeed, as already suggested, the rise of the genuinely multinational corporation with genuinely multinational leadership-and multinational lawyers-may itself be a profound commentary on the increasing irrelevance of national citizenship as a meaningful category for most people, especially if we add to this the observation that many corporations put their own "cultural" stamp on their long-term employees. Even if national citizenship will never become completely irrelevant, one should still contemplate the possibility that it may be taking on the personal meaning that state citizenship has for most of us: It might supply us with teams to root for in basketball or soccer tournaments and, more importantly, with a place from which to vote for national political offices or pay taxes in return for public services. It is, though, ever more unlikely to be of any real import in structuring our identities. There is, I suggest, a deep difference between describing oneself as "coming from North Carolina" (as I do) or even "coming from Texas" (as is the case with my daughters) and "being a North Carolinian," or "being a Texan." At some point, the same may be true of national background. ${ }^{27}$

Imagine, then, that our non-Latvian investor is faced with a recent law passed by the Latvian parliament requiring all factories to be equipped with a certain kind of expensive antipollution device. Despite this law, the parliament does not have a system of enforcement in place, and it is very difficult to detect from surface observation whether the device is being used. Furthermore, the fine imposed, upon discovery, is relatively insubstantial-say, for example, not more than five percent of the cost of the antipollution device. What answer should we expect a lawyer to offer when asked about Latvian "law" on the matter under discussion-that is, under what legal constraints must the profit-maximizing corporation operate? More to the point, might the answer to this question differ depending on the nationality of the lawyer? (This would begin to contextualize the rather abstract notion of "a lawyer" in the preceding sentence: Would different lawyers be likely to present different answers, and which lawyers-and answers-would we prefer in which contexts?)

At the very least, the answer to our question about Latvian law would seem to depend on the comparative attention paid by the lawyer to the behavior of Latvian law enforcement agents, as opposed to the text found in Latvian law books. In this context, at least, Latvia would prefer not a Holmesian (or Lukácsian) lawyer, but a Kronmanian lawyer imbued with civic values and unequivocally

27. Indeed, the word "background" is interesting in this context, for one way of defining this inquiry is establishing the conditions under which one's citizenship status will be "foregrounded," either by the state or, perhaps more significantly, by a lawyer herself. 
committed to the welfare of Latvia as defined by the statute requiring the installation of the antipollution device.

How does Latvia (or any other country) get Kronmanian lawyers? One way might be to announce that a central premise of Latvian jurisprudence is that "law" just is "law on the books," and that lawyers are to pay no attention to "law in action." It should be clear, though, that this is a classic bootstrap argument. No lawyer who is persuaded by Holmesian jurisprudence and who experiences the material success that often attaches to it - at least in the United States, a success Dean Kronman laments-will be impressed by a statement that law is not a prediction of what officials will do (or, for that matter, a similar statement mandating that lawyers take account of social values). Indeed, no state has ever officially promulgated a Holmesian definition of law; all states pretend that their citizens are bound by the law found in law books. None of this would be particularly relevant to a Holmesian lawyer, who would ask whether that statement, defining law nonpredictively, is likely to have any interesting behavioral consequences. We are thus on our way to a classic infinite regress.

Latvia, then, might well doubt that the mere placing of laws on the books would be enough to ensure compliance or, more to the point, even attempts by lawyers to advise their clients to adhere to these laws. What might a state do to increase compliance levels beyond issuing naive pleas for compliance or engaging in the costly hiring of ever more enforcement authorities? One possibility is that Latvia would try to maximize the number of Kronmanian "statesmenlawyers" by ensuring that lawyers are in fact members of the Latvian state, who ostensibly identify with its well-being. This will, Latvia hopes, offer some protection against the swamping of the legal system by lawyers who view themselves as simply the agents of their privateregarding clients, who may be wholly without the kinds of ties to Latvia that might otherwise lead to a commitment to its interests.

By adopting a citizenship requirement, therefore, Latvia is using the formal status of citizenship as a proxy for a certain kind of publicregarding, communitarian sentiment. Latvian nationals, it might be argued, would be more inclined to steer their clients into respecting the desires-and acting to enhance the welfare-of a newly democratic Latvian state even if that state could not provide the enforcement mechanisms necessary to ensure desired behavior from the Holmesian "bad man" who cares only about the costs of given behavior. Does this make much sense, for Latvia or for the United States? We come, finally, to the specifics of In re Griffiths and its rejection, at least within the American context, of such a limitation. 


\section{ON IN RE GRIFFITHS}

Fre Le Poole Griffths, who enjoyed the legal status within the United States of a resident alien, was a citizen of the Netherlands who had married someone then teaching at the Yale Law School. She attended an American law school and then applied, in 1970, to take the Connecticut bar examination. After being refused permission to sit for the examination because of her status as a noncitizen, she sued.

Two cases came down the same day, June 25, 1973, involving the rights of states to restrict certain kinds of positions to citizens. In Sugarman v. Dougall, ${ }^{28}$ the Court, through Justice Blackmun, struck down as violative of the Equal Protection Clause of the Fourteenth Amendment a New York law limiting entry into its civil service to United States citizens. Only then-Justice Rehnquist dissented. Ms. Griffiths's case was similarly disposed of, in a quite brief opinion written by Justice Powell.

The Chief Justice normally would have assigned the same justice to write the majority opinions in such similar cases, and Justice Blackmun was the logical candidate given an earlier opinion he had written dealing with the rights of resident aliens. ${ }^{29}$ I strongly suspect that the assignment of Powell to write Griffiths is explained at least in part by the fact that he had been, before being named to the Court in 1971, president of the American Bar Association. ${ }^{30}$ Who was better suited institutionally to explain to Connecticut, and to the onlooking bar, why states violated the Constitution in limiting bar membership to citizens?

Justice Powell noted that membership in the bar had not traditionally been limited to citizens. Ironically enough, the major source for this observation was an 1873 decision, Bradwell $v$. Illinois, ${ }^{31}$ (in)famous primarily because it upheld Illinois's refusal to admit Myra Bradwell to the bar solely because she was female. Along the way, however, the Bradwell Court noted that admission to the bar "in no sense depends on citizenship of the United States. . . Certainly many prominent and distinguished lawyers have been admitted to practice, both in the State and Federal courts, who were not citizens of the United States or of any State." ${ }^{32}$ Six years after Bradwell, though, in 1879, Connecticut limited admission to the bar

\footnotetext{
28. 413 U.S. 634 (1973).

29. See Graham v. Richardson, 403 U.S. 365 (1971).

30. See JOHN JEFFRIES, LEWIS POWELL 194-204, 210-11 (1994).

31. 83 U.S. (16 Wall.) 130 (1873).

32. Id. at 139, quoted in In re Griffiths, 413 U.S. 717,719 (1973). Indeed, it may also be worth noting that many states at this time allowed at least some resident aliens to vote even in elections for national office, a practice that ended in the United States only in 1928.
} 
to citizens, an action which Justice Powell suggested was the precursor to a host of restrictions adopted throughout the land designed "to impair significantly the efforts of aliens to earn a livelihood in their chosen occupations." 33 Whether motivated by nativism or rentseeking desires of citizens to limit the number of potential competitors, these nationality-based restrictions were, for many years, upheld against challenge.

Beginning in 1948, however, the Court began striking down such laws. ${ }^{34}$ The major breakthrough came in a 1971 case invalidating distinctions between citizens and resident aliens in regard to eligibility for welfare assistance. "[C]lassifications based on alienage," the Court said through Justice Blackmun, "like those based on nationality or race, are inherently suspect and subject to close judicial scrutiny." 35 As specialists know, such scrutiny imposes a very high burden of proof on the state, and few laws have managed to survive it. The Connecticut law, of course, was not such a survivor.

In Griffiths, Connecticut argued, in Justice Powell's words, "that the special role of the lawyer justifies excluding aliens from the practice of law." As an "officer of the court," the lawyer is a quasi-public official, and, according to the Connecticut Supreme Court which had upheld the restriction, courts and the public have a right to "demand [lawyers'] loyalty, confidence and respect" in order to "foster public confidence in the profession and, consequently, the judicial system." 37 The state bar, according to Justice Powell, "contrasts a citizen's undivided allegiance to this country with a resident alien's possible conflict of loyalties." The Connecticut Bar Committee had concluded "that a resident alien lawyer might in the exercise of his functions ignore his responsibilities to the courts or even his client in favor of the interest of a foreign power." 38

The majority was unpersuaded by such arguments, not least because Connecticut offered no evidence supporting the proposition "that the practice of law offers meaningful opportunities adversely to affect the interests of the United States." 39 Justice Powell then included the following very interesting footnote:

Lawyers frequently represent foreign countries and the nationals of such countries in litigation in the courts of the United States,

33. 413 U.S. at 719.

34. See Takahashi v. Fish \& Game Comm'n, 334 U.S. 410 (1948) (striking down California law limiting land ownership to citizens).

35. Graham v. Richardson, 403 U.S. 365, 372 (1971).

36. 413 U.S. at 723.

37. In re Griffiths, 294 A.2d 281, 287 (Conn. 1972).

38. 413 U.S. at 724.

39. Id. 
as well as in other matters in this country. In such representation, the duty of the lawyer, subject to his role as an "officer of the court," is to further the interests of his clients by all lawful means, even when those interests are in conflict with the interests of the United States or of a State. But this representation involves no conflict of interest in the invidious sense. Rather, it casts the lawyer in his honored and traditional role as an authorized but independent agent acting to vindicate the legal rights of a client, whoever it may be. It is conceivable that an alien licensed to practice law in this country could find himself in a position in which he might be called upon to represent his country of citizenship against the United States in circumstances in which there may be a conflict between his obligations to the two countries. In such rare situations, an honorable person, whether an alien or not, would decline the representation. ${ }^{40}$

Justice Powell further suggested that Connecticut's interest in ensuring the loyalty of its lawyers could be adequately served by a requirement that members of the bar take an "attorney's oath" of integrity in the practice of law and a "commissioner's oath" to "support the constitution of the United States, and the constitution of the state of Connecticut." 41 Ms. Griffith was completely willing to give both oaths. ${ }^{42}$ It is, of course, hardly clear what such pledges entail, at least in the absence of a strong theory of constitutional interpretation that resolves potentially conflicting visions of constitutional fidelity. ${ }^{43}$ Perhaps for this reason, the Court was quick to point out that Connecticut could also "properly conduct a character investigation" and maintain "continuing scrutiny," coupled with the prospect of bar discipline, "in order to vindicate its undoubted interest in high professional standards." 44

Chief Justice Burger, who had joined the majority in Sugarman, which dealt with the general civil service, dissented in In re Griffiths, and was joined by then-Justice Rehnquist. Although Burger hinted that he was ambivalent about the wisdom of the majority's relative disdain for the importance of citizenship, the primary ground for his dissent was simply the right of a state, in our federal system of government, to adopt a policy whether or not the Supreme Court believes it to be wise. It is, said Burger, "reasonable . . . for a State to conclude that persons owing first loyalty to this country will grasp

\footnotetext{
40. Id. at 724 n.14.

41. Id. at $725-26$.

42. Id. at 726 .

43. I have explored such questions in SANFORD LEVINSON, CONSTITUTIONAL FAITH 90-154 (1988).

44. 413 U.S. at $726-27$.
} 
[its] traditions and apply our concepts more than those who seek the benefits of American citizenship [such as the right to practice law] while declining to accept the burdens of citizenship in this country." 45 Obviously, Burger believed that being a lawyer is significantly different from being an ordinary state bureaucrat and that the state can, in effect, express more concern about who becomes the former than the latter.

When faced with a similar case, the Canadian Supreme Court came to the same decision as did the majority of the United States Supreme Court, though also over vigorous dissent. A Canadian trial judge had upheld the limitation of membership in the bar to Canadian citizens, arguing that "citizenship [is] a personal characteristic which is relevant to the practice of law on account of the special commitment to the community which citizenship involves and not merely because the practical familiarity with the country necessary for the occupation can generally be expected in the case of citizens." ${ }^{46}$ On appeal, the Court rejected this reasoning. "Only those citizens who are not natural-born Canadians," said Judge McLachlin,

can be said to have made a conscious choice to establish themselves here permanently and to opt for full participation in the Canadian social process. ... While no doubt most citizens, natural-born or otherwise, are committed to Canadian society, citizenship does not ensure that that is the case. Conversely, non-citizens may be deeply committed to our country. Moreover, the requirement of commitment to our country is arguably satisfied by the oath of allegiance which lawyers are required to take. An alien may swear that oath. In any event an alien may owe allegiance to the Crown if he is resident within this country, even if he does not take the oath of allegiance. ${ }^{47}$

Judge McLachlin's reasoning was essentially accepted by a majority of the Canadian Supreme Court.

Two of the five Justices, however, dissented, subscribing to the view that citizenship was a rational proxy for "a commitment to the country and to the fulfillment of the important tasks" carried out by lawyers. "Citizenship," said the dissenters, "require[s] the taking on of obligations and commitments to the community, difficult sometimes to describe but felt and understood by most citizens." ${ }^{48}$ They readily

45. Id. at 733 (Burger, C.J., dissenting).

46. See Andrews v. Law Soc'y, 22 D.L.R.4th 9, 21 (1986), quoted in Andrews v. Law Soc'y, 56 D.L.R.4th 1, 35 (1989) (emphasis added). I am grateful to Lorraine Weinrib and Alex Aleinikoff, who informed me of the existence of Andrews and its obvious relevance to my project.

47. 27 D.L.R.4th $600,612-13$ (1986), quoted in 56 D.L.R.4th at 43.

48. See 56 D.L.R.4th at 29 (McIntire, J., dissenting). 
conceded that citizenship is neither a necessary nor sufficient condition to ensure the requisite commitment, but " $[\mathrm{t}] \mathrm{o}$ abolish the requirement of citizenship on the basis that it would fail to insure the attainment of its objectives would ... be akin to abolishing the law against theft, for it has certainly not insured the elimination of that crime. $" 49$

The general issue of public-employment rights of noncitizens has generated extensive case law within the United States, of which Sugarman and In re Griffiths were only the beginning. The Supreme Court has, for example, upheld the limitation of employment to citizens in the case of members of a state police force ${ }^{50}$ and of probation officers within the criminal justice system. ${ }^{51}$ It has also struck down citizenship requirements such as a Texas law attempting to prohibit resident aliens from becoming notaries public. ${ }^{52}$ The Court has adopted a "'political function' exception" 53 to the rules announced in Sugarman and In re Griffiths, which has been invoked in regard "to laws that exclude aliens from positions intimately related to the process of democratic self-governance." 54

Perhaps the most interesting application, in regard to the issues raised by this essay, of this "political function" test was in Ambach v. Norwich, ${ }^{55}$ which upheld New York's ban on having "aliens who have not declared their intent to become citizens" teach in public schools. Justifying its decision, the Court described public school teachers as "possess[ing] a high degree of responsibility and discretion in the fulfillment of a basic governmental obligation." Teachers not only "have direct, day-to-day contact with students [and] exercise unsupervised discretion over them," but also "act as role models, and influence their students about the government and the political process." $" 56$ For all of these reasons, a state may choose to limit public-school teaching, and other similar roles, to "full-fledged members" of the political community, at least as that is measured by the formal status of citizenship.

One could, of course, devote an entire essay to the relevance of citizenship to public-school teaching. Suffice it to say for now that I find it difficult to distinguish lawyering from school teaching or working in the criminal justice system. Lawyers often exercise a

49. Id.

50. Foley v. Connelie, 435 U.S. 291 (1978).

51. Cabell v. Chavey-Salido, 454 U.S. 432 (1982).

52. Bernal v. Fainter, 467 U.S. 216 (1984).

53. Id. at 220 .

54. Id.

55. 441 U.S 68 (1979).

56. Bernal, 467 U.S. at 220. 
significant degree of discretion in relating to their clients; far more to the point, one might well argue that a central role of lawyers should be to influence their clients in regard to legal obligations. That is, one might desire that the lawyer be something more than the basically amoral Holmesian predictor and instead adopt a more Kronmanian role, actively remonstrating with the client to adhere to legal duties even if the prospects of enforcement are relatively low. It is also worth mentioning that a patriot-lawyer might remonstrate with the client, under some circumstances, to forgo enjoying certain legal rights because of their impact on important social values, including the general health of the polity. Under this conception, lawyers identifying themselves as committed citizens of the polity and friends of its claims as well as the client's, would view their role as including conversation with clients about the meaning of engaged citizenship.

Such a conception can be found even within the norms of professional conduct promulgated by the American Bar Association and adopted by many states. Thus the A.B.A. has indicated that "[a]dvice of a lawyer to his client need not be confined to purely legal considerations .... In assisting his client to reach a proper decision, it is often desirable for a lawyer to point out those factors which may lead to a decision that is morally just as well as legally permissible." 57

There is, it should be said, no reason to believe that the desires of the state are themselves necessarily moral, which calls into question the organized bar's flat prohibition on "counsel[ing] a client to engage ... in conduct that the lawyer knows is criminal." 58 There is no reason for a lawyer (or anyone else) to be a thoughtless cheerleader for the law; I accept a notion of good citizenship that includes willingness not only to forgo voluntarily one's legal rights, but also, under some circumstances, to defy the law. But this notion of engaged lawyering (or engaged citizenship) is light-years away from the Holmesian view of the lawyer as austere instrument of the client, which now prevails.

57. MOdel CODE of PROfEsSional Responsibility EC 7-8 (1969); see also Model RULES OF PROFESSIONAL CONDUCT Rule 2.1 (1983) ("In rendering advice, a lawyer may refer not only to law but to other considerations such as moral, economic, social, and political factors, that may be relevant to the client's situation."). I can testify that few law students seem to find such a potential role as moral counselor attractive or even plausible. Most view any such role as an incursion into the autonomy of the client, who is presumed either to have thought through in advance any moral or political dilemmas or to be impervious to the lawyer's own potential suggestions. Full analysis of the actual impact of the ABA's delineation of the lawyer's role is far beyond the scope of this essay.

58. MOdel Rules of Professional Conduct Rule 1.2(b) (1983). 


\section{The LaWyer as TRansmitter of CoRe Political Values}

Let me turn once more to asking what it is that lawyers-or, for that matter, school teachers-do. This time I would like to contrast the conception of the lawyer (or teacher) as simply the possessor of certain cognitive skills or bodies of information with a quite different conception that emphasizes the role played by the lawyer (or teacher) as a transmitter of cultural norms and, indeed, as a model of what it might mean to conceive of oneself as a member of an overarching political community. It may be, of course, that the actuality of felt membership is so weak, when all is said and done, as to make a mockery of the kinds of analyses described above that give great weight to the status of citizenship.

I suggest that what has come to be called the "standard view" of the lawyer's role presents a remarkably thin conception of political membership, including that formalization of membership called citizenship. Consider, for example, what may be the most famous articulation of the lawyer's duty of zealous loyalty to a client. Although the author is Lord Henry Brougham, an English lawyer of the early nineteenth century, the sentiment can be found in almost any contemporary American examination of professional responsibility:

An advocate, in the discharge of his duty, knows but one person in all the world, and that person is his client. To save that client by all means and expedients, and at all hazards and costs to other persons, and, amongst them, to himself, is his first and only duty; and in performing this duty he must not regard the alarm, the torments, the destruction which he may bring upon others. Separating the duty of a patriot from that of an advocate, he must go on reckless of consequences, though it should be his unhappy fate to involve his country in confusion. ${ }^{59}$

In that particular instance, Lord Brougham was threatening to defend his client, Queen Caroline, against King George IV's accusations of adultery, by revealing the King's secret marriage to a Catholic, which violated the Act of Settlement of 1689 and would presumably have cost George his crown and, more importantly, caused a significant political crisis. Lord Brougham's comment is often quoted for its tone of professed indifference to the "torments" and "destruction" that the

59. Quoted in DAVID LubAN, LAWYERS AND JUSTICE 54-55 (1988). Luban's book is obviously relevant to the general issues presented in this essay, especially insofar as he offers a vigorous critique of Holmesian lawyering. Id. at 20-30. I focus on Dean Kronman's book instead because it is more self-consciously written within the civic republican critique of the kind of egoistic liberalism linked with Holmes. 
lawyer, in the course of vigorous advocacy, might be visiting upon adversaries or, even worse, innocent third parties. That indifference obviously raises important questions about the morality of the advocate's enterprise, which has generated hostile response at least since Plato's scathing critique of oratory in the Gorgias. ${ }^{60}$ But I want to focus more on the "separat[ion of] the duty of the patriot from that of the advocate," for this seems to suggest that the lawyer can, at some level, cast off the constraints of citizenship (assuming that this is a proxy for patriotism) when such constraints would interfere with the lawyer's primary duty of zealous commitment to the interests of the client. To be sure, a lawyer is never entitled, at least from the perspective of those in control of the legal system, to act "illegally" on behalf of a client (though this observation only underscores the importance of having a cogent theory of what constitutes "the law"); but a lawyer is permitted, indeed encouraged, according to a common understanding of the professional role, to assert with vigor any and all nonfrivolous claims that a client might make, regardless of the social cost they might entail.

What are we to think of such a conception of professional responsibility? Is it fair to suggest that our answer will depend, at least in part, on the extent to which we ourselves feel relatively little patriotism or are otherwise suspicious of strong notions of national loyalty? Also important, I suspect, is the extent to which we adopt a strongly individualist view of the world that regards institutions, including the nation-state, primarily as threats to individual liberty, identity, or even the possibility of a moral life. It is quite possible, then, that "citizenship" need not carry as one of its meanings any particular feelings of friendship toward the political order.

Indeed, that view characterizes much of American political thought. Many of our political forbearers were influenced by antistatist versions of eighteenth-century political thought that have survived into our late-twentieth-century world. Furthermore, it must also surely be relevant that so much of our population is composed of emigrants (and their offspring) from other countries and cultures who, by definition, were sufficiently "unencumbered" to find tolerable and even attractive the abandonment of old loyalties and identities and the move to what indeed would become a very new world. To be sure, it is difficult to understand American culture without paying attention to aspects of American nationalism and, some would say, chauvinism. That said, however, I wonder how much the view that "No one is going to push us around!" or that "We're number one!"

60. See Plato, Gorgias (Terence Irwin trans. 1979). 
translates into a notion of community that leads one to identify with the travails of strangers who share "only" common membership in our polity.

It seems ever harder in the United States to envision a sense of shared enterprise and loyalties that might, for example, lead a lawyer to press, in conversation with the client, the claims of citizens likely to be hurt by the client's proposed course of action, let alone to refuse work from that client. One wonders how much this is increasingly true of Europe as well. Even as Eastern Europe, in particular, offers daily examples of the most virulent forms of nationalism, we must recall that the diminution of traditional borders-and, therefore, of identity-continues in Western Europe. To the extent that national barriers will fall in the legal marketplace, as well as others, one would expect a diminishing concern on the part of many legal professionals with the consequences of their clients' activities-unless, of course, it turns out that a London lawyer will indeed feel sufficiently "European" to care deeply about the fate of, say, Italy, or that an Italian lawyer will feel sufficiently "Northern" to care about the fate of, say, the Netherlands.

\section{A DigRESSION ON "RESIDENCE"}

I have been emphasizing the (ir)relevance of formal membership in a polity, as symbolized by the passport one carries. But perhaps one can argue that the relevant inquiry is really more "informal" and empirical; that is, we might choose to focus on the realities of residence rather than the legal formalities of citizenship. One can readily believe that someone who lives in Latvia or Texas, regardless of his or her formal citizenship, would in fact be more concerned about Latvian or Texan welfare than a "Latvian" or "Texan" choosing to live elsewhere. The reason for this belief has nothing to do with the perhaps implausible sociopsychological assumptions underlying an emphasis on altruism or civic republicanism and everything to do with what most of us regard as altogether "normal" incentives to look after one's own personal interests. After all, should the quality of life in Latvia or Texas be diminished, through pollution or whatever else, residents themselves (including, of course, the lawyer) will pay the cost.

Resident lawyers would have every incentive to limit blind commitment to the client's interests if the realization of those interests would in fact be costly to themselves and their families. One assumes that only the most "disciplined" lawyers will accept without question the imposition of increased risks on their children, even if they are all too willing to foist such risks on the children of others. At the very least, 
one might count on such lawyers to bring to their clients' attention the potential social costs of the policies under contemplation, even if one expects the lawyer to go loyally ahead and attempt to attain the clients' goals upon a declaration that the clients are utterly indifferent to the costs and are interested only in maximizing profits.

Interestingly enough, the United States Supreme Court has invalidated most state attempts to limit bar membership to state residents. ${ }^{61}$ And, I confess, I support all such invalidations, for the state policies strike me as far more describable as objectionable barriers to entry mounted by a bar monopoly than as public-regarding regulations designed to protect important civil interests. Similarly, no one alive during the 1960s can forget the importance of "outside" lawyers who were willing to brave the courthouses of the Deep South in the struggle for civil rights and basic justice. Indeed, reference to the prereformed Deep South makes one aware as well of the potential costs of a too-quick acceptance of Kronman's elegiac evocation of membership in a common community by client, lawyer, and judge, as well as his emphasis on incremental prudentialism as the keystone to lawyerly statesmanship. There is almost no place in his scheme for the "outside troublemaker" who views the community as fundamentally flawed and in need of radical transformation.

But this may simply be to recognize that life is complex and policies can never be analyzed outside of the specific contexts from which they spring. It is possible, therefore, that the factors leading me to express at least a modicum of sympathy for the exclusion of noncitizens from the practice of law might lead me to reconsider at least in part my opposition to limitation on the basis of residency.

\section{CONCLUSION}

So where now do I stand in regard to In re Griffith and the limitation of entrance to the legal profession to American nationals? At the very least, I am now considerably more ambivalent than I was before my trip to Hungary and my encounter with Ms. Jansone and her resistance to the idea of a "cosmopolitan" bar. It no longer strikes me as bigoted or unthinkingly tribalistic to desire that those who join the legal profession, and subject themselves to the norms of professional culture, feel as well the pull of other loyalties-the most important one, for our purposes, being the constellation of emotions and identifications often linked with citizenship.

61. See, e.g., Barnard v. Thorstenn, 489 U.S. 546 (1989); District of Columbia Court of Appeals v. Feldman, 460 U.S. 462 (1983). 
That being said, I must also say that I do not see in the contemporary United States a culture that takes citizenship sufficiently seriously to justify the distinction that Connecticut wanted to draw. Connecticut's limitation of bar membership to American citizens-interestingly enough, Connecticut did not care if its lawyer were citizens of Connecticut itself-seems more meanspirited, not to mention economically protectionist, than expressive of a rich conception of political community.

I see no meaningful way of turning back toward a richer conception, even if one finds it attractive rather than potentially frightening. I am inclined, though, to think that this is far more a statement about life in the contemporary United States than it is a general truth about how societies should conduct themselves. Small, vulnerable societies, concerned with preserving (or restoring) a particularistic culture against the perceived threat of being overwhelmed by cultural outsiders, might legitimately reach different conclusions from our own about the attributes deemed desirable in those who would practice law. At bottom, I suppose the question raised by countries like Latvia is whether we respect them-and their desire not to become cosmopolitan and "multicultural"-enough to allow them, without criticism, to limit such socially complex occupations as lawyering (or school teaching) to their own citizens.

Perhaps Latvia - not to mention its neighbors to the south in the Balkans-simply illustrates the dreadful ambiguity of the Wilsonian focus on national self-determination. After all, that legacy, so central to American politics in the ensuing seventy-five years, seems to emphasize the legitimacy of groups defined by nationality (or ethnicity) gaining political control over given territory and, therefore, being able to use the coercive power of the state to maintain their national identity. As Daniel Patrick Moynihan eloquently notes, there are good reasons to lament aspects of the Wilsonian heritage. ${ }^{62}$ Nationalism that is unleavened by liberalism is frightening indeed. ${ }^{63}$

I confess that I myself have no wish to live in a political order defined by ethnicity. I count it as one of the glories of the United States that it is not a true nation-state, but, rather, a political state composed of many nations. Even if I sometimes think that the American conception of citizenship is too thin, I have no desire to make it very thick. I much prefer the integrative and antinationalist developments in Western Europe over the rediscovery of nationalist roots that seems to pervade contemporary Eastern Europe.

62. See Daniel Patrick Moynihan, Pandemonium 63-106 (1993).

63. See Yael Tamir, Liberal Nationalism (1993). 
Still, one meaning of "multiculturalism" is a respect for particularistic cultures, including their desire to maintain their distinctiveness in a cosmopolitan world. And a central question posed by multiculturalism is whether those who are not members of (or who do not otherwise identify with) a given culture can sufficiently appreciate challenges to it or accept the necessity of certain measures to maintain it. I cannot reject as "irrational" a belief that citizenship may be a significant marker of commitment in small (and vulnerable) polities, even though it may not be in larger (and less vulnerable) ones like our own. I am still not at the point of supporting the Latvian prohibition of noncitizen lawyers, but, perhaps more importantly, I can no longer bring myself to condemn it. As Justice Holmes famously put it, "General propositions do not decide concrete cases." 64 Whether discussing Connecticut, Canada, or Latvia, one must pay close attention to context in determining the relevance of citizenship (or residence) to such social roles as lawyering.

64. Lochner v. New York, 198 U.S. 45, 76 (1905). 